\title{
REVISITING AMERICANUS NOVUS: ANGLICIZATION CRISIS AND SALEM WITCH TRIALS IN SEVENTEENTH CENTURY NEW ENGLAND ${ }^{1}$
}

\author{
Yonca DENIZZARSLANI*
}

\begin{abstract}
Nations like narratives, lose their origins in the myth of time and only fully realize their horizons in the mind's eye. Such an image of the nation - or narration- might seem impossibly romantic and excessively metaphorical, but it is from those traditions of political thought and literary language that the nation emerges as a powerful historical idea in the west.

Homi K. Bhabha / Nation and Narration
\end{abstract}

\begin{abstract}
In the quadricentennial of the founding of Plymouth Plantation, recent challenges in the United States politics and society raise critical questions on American identity and American democracy. Thus, calling for a revisit on the seventeenth century northeastern American experience of English colonizers, contemporary academia is engaged in new approaches and perspectives on American history and historicism, whereby a peculiar sense of past and act of remembrance count for present day cultural and political dilemmas across the United States. The legacy of early founders and pioneers of New England colonies provides a host of historicism on Anglo-American identity, which was elaborately imprinted in colonial accounts on material culture, legal, military, political and religious practices in the nexus of intra- and extra-imperial encounters of metropole and the colony itself. This article aims to examine the theological and political grounds for 169293 Salem witch trial accounts by Cotton Mather in his The Wonders of the Invisible World: Being

${ }^{1}$ This study is developed within the scope of my post-doctoral academic research project entitled as "Bodies Scribed / Textual and Corporal Representations of Authority and Transgression: Religious and Political Symbolism of Criminality and Corporal Punishments in Early Colonial New England," carried out at Harvard University, Department of History between September 2017 and June 2018.

* Assist. Prof., Ege University, Faculty of Letters, The Department of American Culture and Literature, Bornova-IZZMIR. E-mail: yonca.denizarslani@ege.edu.tr. ORCID: 0000-0002-37629553
\end{abstract}

(Makale Gönderim Tarihi: 15.10.2019 - Makale Kabul Tarihi: 04.12.2019) 
An Account of the Tryals of Several Witches Lately Executed In New England (1692) as a reflection of post-1691 Anglicization crisis in New England.

Keywords: Anglo-American identity, colonialism, Anglicization, witchcraft

Öz

Yeni Amerikalı'ya Yeniden Bir Bakış: On yedinci Yüzyıl New England'ında Anglikanlaşma Krizi ve Salem Cadı Mahkemeleri

Plymouth Sömürgesinin 400. kuruluş yıldönümünde günümüz Amerika Birleşik Devletleri’ndeki siyasi ve toplumsal krizler Amerikan kimliği ve Amerikan demokrasisi üzerine belli sorgulamaları da beraberinde getirmektedir. Böylece, Amerika Birleşik Devletleri iç ve dış siyasetindeki mevcut siyasi çatışmaların kültürel art alanı olarak görülen özel ulusal tarihî bellek algısı bağlamında, günümüz akademik çalı̧̧malarında, Amerikan tarihi ve tarihçiliği üzerine yeni yaklaşımlar çerçevesinde, İngiliz sömürgecilerin on yedinci yüzyıl kuzeydoğu Amerika deneyimlerini yeniden değerlendirmek kaçınılmaz olmuştur. New England sömürgelerinin öncü kurucuları, kuzeydoğu Anglo-Amerikan kimliğinin temeli olarak, dönemin iç ve diş emperyalist dengelerinin ağında gelişmiş anakent ve sömürge ilişkilerinin yansıdığı materyal kültür, hukukî, askerî, siyasî ve dinî deneyimlerin aktarıldığı zengin bir sömürge yazınını miras bırakmışlardır. $\mathrm{Bu}$ çalışma, Cotton Mather'ın, 1692-93 Salem cadı mahkemelerinin teolojik ve siyasi gerekçelerini savunduğu The Wonders of the Invisible World: Being An Account of the Tryals of Several Witches Lately Executed In New England (1692) adlı kitabın1, New England'da 1691 sonrası gelişen Anglikanlaşma krizinin bir yansıması olarak incelemeyi amaçlamaktadır.

Anahtar Kelimeler: Anglo-Amerikan kimliği, sömürgecilik, Anglikanlaşma, cadılık

\section{Introduction: Initial Disintegration between the Colony and the Metropole / Colonial Autonomy Prior to the Late Seventeenth Century Anglicization Process}

The Puritans of early New England have been a focus of attention most prominently with their piety and religious fervor projected through their body politic as their unique American experiment. Accordingly, there has been an abundance of histories, which contributed to this utmost theological emphasis on colonial American experience and American identity. For instance, the manner in which Cotton Mather gathered the lives of early New England governors in his Magnalia Christi Americana; or, Ecclesiastical History of New England (1702) was not only monumental in the sense that he portrayed the early Puritan leaders almost as prophetic figures, but also a counter reaction to the Second Charter (1691) and its Anglicization period with a tone of mourning for the fallen era of the colonial Calvinist Puritan legacy. In this respect, Ralph Bauer calls Mather's Magnalia as an Anglo-American creole form of writing considering that Mather drew a distinctive colonial identity as an answer to the rising criticism on the political and religious re-organization of early New England:

In 1684, the charter of Massachusetts Bay was revoked, and the New England elite was left in perpetual struggle with the insular governors now sent 
Revisiting Americanus Novus:Anglicization Crisis and Salem Witch Trials in Seventeenth Century New England

to the colonies from London. It was in part the attempt to counterpoint these "late oppressors of New England" that inspired Cotton Mather's patriotic biographies of New England's leading personages during the seventeenth century in his Magnalia Christi Americana (1702)-perhaps the most monumental expression of an emerging creole consciousness in colonial British America. $^{2}$

Thus, Cotton Mather's Magnalia can also be read as a textual representation of political and cultural anxieties raised by the seventeenth century fin de siècle of Anglicization process as the Massachusetts Bay Colony became a royal colony with the Second Charter in 1691. Prior to this Anglicization process, the initial seventeenth century sense of political and sectarian disintegration from the metropole London, and its offshoots in colonial autonomy can be observed in a plethora of pioneering accounts which emphasized not only a spatial distance but also an ideological detachment from the homeland. Hence, the magisterial colonial legal practices in the absence of a common law almost until the mid-seventeenth century was an example for the persistence of this earlier colonial disintegration and autonomy from the metropole. Until the enactment of The Book of the General Laws and Liberties Concerning Inhabitants of the Massachusetts in 1647, Massachusetts Bay Colony had a relatively autonomous governance guaranteed by The Charter of Massachusetts Bay (1629):

In all and every, or any of which saide greate and generall Courts soe assembled, Wee doe for Us, our Heires and Successors, give and graunte to the said Governor and Company, and their Successors, That the Governor, or in his absence, the Deputie Governor of the saide Company for the tyme being, and such of the Assistants and Freeman of the saide as shalbe present, or the greater number of them so assembled, whereof the Governor or Deputie Governor and six of the Assistants at the least to be seaven, shall have full Power and authoritie to choose, nominate, and appointe, such and soe many others as they shall think fill and requisite, for the ordering managing, and dispatching of the Affaires of the saide Governor and the Company, and their successors; And make Lawes and Ordinances for the Good and Welfare of the saide Company, and for the Government and ordering of the saide Lands and Plantation, and the People inhabiting and to inhabite the same, as to them from tyme to tyme shalbe thought meete, soe as such Lawes and Ordinances be not contrarie or repugnant to the Lawes and Status of this our Realme of England. ${ }^{3}$

\footnotetext{
${ }^{2}$ Bauer \& Mazzotti 2009, p. 31.

${ }^{3}$ The Charter of Massachusetts Bay (1629). Retrieved from The Avalon Project, Documents in Law, History and Diplomacy
} 
Besides its ambiguous legal scope, The Charter of Massachusetts Bay (1629) affirmed the establishment of a colonial self-government by giving ultimate authority and jurisdiction to the governor, deputy governor and the assistants for making laws and ordinances. Accordingly, legal institutions and structures mattered in determining the civic liberties of the first decades of the early colonial New England. Colonial settlements were established either with contracts or royal charters including the terms and conditions regulated both by the investors and the crown. This legal condition gave the early Massachusetts Bay magistrates a freedom to expose their discretionary penal practices based on the Mosaic Laws besides English criminal laws. To the extent they followed the rights and liberties stated in the royal charter, then, early governors had a relevant autonomy to expose their rule in the settlement. This was also the reason behind their resistance to the prolonged legal process for the establishment of the common law between 1629 and $1648 .{ }^{4}$ Whereas the political and economic strength, guaranteed by the royal charter, was meant for their lineage to the English legal traditions, their autonomy in governing the settlement sustained their cause to implant and establish themselves in the New World. Thus, in contrast to Chesapeake colonies, which were primarily profitbased with a high population of single male servitude, Massachusetts Bay Colony's highly educated, well-to-do gentry who migrated as family units and promoted such migrant profiles with professional occupations in trade, law and theology, drew a distinctive path in seventeenth century mainland North American colonization. ${ }^{5}$ Far away from the Anglican church-state domain of their metropole London, early Calvinist New England's founding figures established a civic authority, a Reformed form of body politic, peculiar to colonial conditions shaped by their American experience. Kathleen Donegan emphasizes the trope of body as an ideologically contested colonial site: "We must first understand how English peoples conceptualized and represented life in the colonies as a bodily experience." 6 According to Donegan, then, “...the body appears as a primary conveyance through which protracted negotiations between English and colonial life was conducted." ${ }^{7}$ Furthermore, she refers to Jim Egan's argument on the influence of the concept of 'the experienced colonial body' in relevance to its peculiar formulation in colonial body politic: "In order to insert themselves into the social and political hierarchies of colonialism without disrupting its goals, he argues, colonial writers formulated a model of civic authority that allowed them to revise the figure of body politic

\footnotetext{
${ }^{4}$ McManus 1993, p. 6.

${ }^{5}$ Nelson 2008, p. 52.

${ }^{6}$ Donegan 2002, p. 10.

${ }^{7}$ Donegan 2002, p. 10.
} 
Revisiting Americanus Novus:Anglicization Crisis and Salem Witch Trials in Seventeenth Century New England

while bolstering their status as English subjects." ${ }^{8}$ With regard to the inherent conveyance of colony versus metropole dichotomy in colonial body politic, Donegan questions the validity of a commonly accepted diachronic lineage of colonial, pre-Revolutionary and post-Revolutionary American identity:

One of the most contested sites in early American studies is also one of the broadest: the space of colonial identity itself.... Whether their (scholars') arguments have rested on exceptionalism or continuity, creolization or internationalism, ideology or materiality, establishments or borderlands, most have posited a linear design of transformation, one in which "the colonial" stretches out as a long evolutionary course between an English "before" and an American "after." "

Hence, the anxieties raised by this ideological and political disintegration from the metropole can be observed as a predominating motif in The Mayflower Compact (1620), signed by the Separatist Pilgrims under the leadership of William Bradford, and the Congregationalist Puritan leader John Winthrop's sermon "A Modell of Christian Charity" (1630). It is noteworthy that both of these founding texts were written on their course across the Atlantic. The Mayflower Compact was designed on board the ship Mayflower and Winthrop's sermon was given on board the ship Arabella. Regarding these early settlers' discord with the Church of England and their grounds for establishing their own polities, projected in accordance with their Calvinist notion of Providence, these two pioneering transatlantic voyages towards northeastern America can also be seen as a metaphorical Exodus experience as they set sail towards their New Canaan, which was a frequently recurring Biblical typology on their perception of the New World. A decade earlier than John Winthrop's Massachusetts Bay Colony (1630), William Bradford's Pilgrims founded the Plymouth Plantation. Nevertheless, having departed from their exilic experience in Holland, William Bradford's Separatist Pilgrims' disintegration (who separated themselves from the Church of England) from the metropole was a further dismantling experience than that of John Winthrop's Congregationalist Puritans (who remained as members of the Church of England). Accordingly, this early experience of sectarian divergence between Separatism and Congregationalism marked a preconditioned colonial imperative of church-state governance despite its Reformed stance. However, despite their denial of membership to the Church of England and its relevant requirements for political subjection, William Bradford's Pilgrims on the Mayflower ship were highly anxious for not having a set of rules for self-governance as their ship was driven off course

\footnotetext{
${ }^{8}$ Donegan 2002, p. 10

${ }^{9}$ Donegan 2002, p. 9.
} 
from its route to the Virginia Colony. Thus, on their route, away from the legal jurisdiction of Anglican Virginia Colony, they set their rules of self-governance and signed it on board the ship. Consequently, instead of anchoring in northern Virginia, the Pilgrims landed in Massachusetts near Cape Cod and founded the Plymouth Plantation. Moreover, considering the fact that the number of undersigned Pilgrims was barely half of the total sum of 102 passengers, The Mayflower Compact was not only the first example of a social contract but also a unique founding document germinating the initial roots of oligarchic democracy in the New World:

IN THE NAME OF GOD, AMEN. We, whose names are underwritten, the Loyal subjects of our dread Sovereign Lord King James, by the Grace of God, of Great Britain, France, and Ireland, King, Defender of the Faith, \&c. Having undertaken for the Glory of God, and Advancement of the Christian Faith, and the Honour of our King and Country, a voyage to plant the first Colony in the northern Parts of Virginia; Do by these Presents, solemnly and mutually, in the Presence of God and one another, covenant and combine ourselves together into a civil Body Politic, for our better Ordering and Preservation, and Furtherance of the Ends aforesaid: And by Virtue hereof do enact, constitute, and frame, such just and equal Laws, Ordinances, Acts, Constitutions, and Officers, from time to time, as shall be thought most meet and convenient for the general Good of the Colony; onto which we promise all due Submission and Obedience. ${ }^{10}$

Examining the rhetoric of The Mayflower Compact, one is to realize a heightened sense of political legitimacy dwelled in the articulation of loyalty to King James I. Given the fact that the Pilgrims' initial pact was with Virginia Colony (a trading company chartered by King James I) to settle on the lands in northern Virginia, they were financed by London stockholders. This fact raises a question: In what sense should we take The Mayflower Compact as the first New World document of self-governance? The answer comes through the rhetorical layers of the following half of the document:

Do by these Presents, solemnly and mutually, in the Presence of God and one another, covenant and combine ourselves together into a civil Body Politic, for our better Ordering and Preservation, and Furtherance of the Ends aforesaid: And by Virtue hereof do enact, constitute, and frame, such just and equal Laws, Ordinances, Acts, Constitutions, and Officers, from time to time, as shall be thought most meet and convenient for the general Good of the Colony; onto which we promise all due Submission and Obedience.

10 The Mayflower Compact. From Dreisbach \& Hall 2009, p. 86-7. 
Revisiting Americanus Novus:Anglicization Crisis and Salem Witch Trials in Seventeenth Century New England

First of all, it is explicitly understood that mutuality between the parties of the covenant does not rest in between the colonials and the Church of England of metropole London or its offshoots elsewhere in the New World, but between the colonials and the colonial governance to be embodied in 'Laws, Ordinances, Acts, Constitutions, and Officers' in their future plantation. In this respect, designed outside the domain of its contemporary ecclesiastical jurisdiction of the Church of England, The Mayflower Compact was uniquely a historical turn in Western political tradition of civic society. From this emphasis on, the initial expression of their loyalty to the crown is mystified behind the following definition of being covenanted into a body politic for their "better Ordering and Preservation, and Furtherance of the Ends aforesaid." Here, the emphasis is transferred to the expression of 'better Ordering and Preservation' that is attached to the 'Furtherance of the Ends aforesaid,' which were primarily meant for the 'Advancement of the Christian Faith' for the 'Glory of God.' Thus, the intention of planting the first colony in northern parts of Virginia for honoring the 'King and Country' sounds subsidiary in the sequence of the sentence: "Having undertaken for the Glory of God, and Advancement of the Christian Faith, and the Honour of our King and Country, a voyage to plant the first Colony in the northern Parts of Virginia." To indicate more on the Reformed hierarchy implied by the expression of 'better Ordering and Preservation,' Max Weber's thesis The Protestant Ethic and The Spirit of Capitalism (1930) will be helpful:

It seems at first a mystery how the undoubted superiority of Calvinism in social organization can be connected with this tendency to tear the individual away from the closed ties with which he is bound to this world. But, however strange it may seem, it follows from the peculiar form which the Christian brotherly love was forced to take under the pressure of the inner isolation of the individual through the Calvinist faith. In the first place it follows dogmatically. The world exists to serve the glorification of God and for that purpose alone. The elected Christian is in the world only to increase this glory of God by fulfilling His commandments to the best of his ability. But God requires social achievement of the Christian because He wills that social life shall be organized according to His commandments, in accordance with that purpose. The social activity of the Christian in the world is solely activity in majorem gloriam Dei. This character is hence shared by labour in a calling which serves the mundane life of the community. ${ }^{11}$

In regard with Weber's reference to Calvinist inner-worldly asceticism and the concept of calling in a worldly activity, then, The Mayflower Compact's

\footnotetext{
${ }^{11}$ Weber 1930, p. 64.
} 
substitution of ecclesiastical order with social order - namely that of civil body politic - was a profound rhetoric of a Reformed society. Thus, through the textual layers of their body politic, the Separatist Pilgrims denounced their lineage to the Church of England and its political offshoots which were legitimized with the Act of Supremacy (1534) and the Act of Uniformity (1559) in the sixteenth century, following the break with the Roman Church by Henry VIII.

Having exemplified the rhetorical representation of early colonial phenomenon of political and sectarian disintegration of New England venture via The Mayflower Compact (1620), a second focus on John Winthrop's sermon "A Modell of Christian Charity" (1630) brings forth a different understanding of colonial ecclesiastical authority, underlining a sectarian and political divergence between Separatism of the Plymouth Plantation and Congregationalism of the Massachusetts Bay Colony. First of all, John Winthrop's initial denouncement of the Old World political and religious bonds is implied through his evocation of the Reformed idea of Providence:

First, to hold conformity with the rest of his works, being delighted to shewe forthe the glory of his power, in ordering all these differences for the preservacion and good of the whole, and the glory of his greatness that as it is the glory of princes to haue many officers, soe this great King will haue many Stewards counting himself more honoured in dispenceing his guifts to man by man, then if hee did it by his owne immediate hand. ${ }^{12}$

Based on the convergence of John Calvin's Reformed principle of 'predestination' and the Biblical 'Promised Land,' the notion of 'Providence' within these lines appears as a twofold realm in Puritan theology. Firstly, the utmost implication of Providence was primarily meant for God's absolute will to show his power onto his works. Secondly, relying on this unconditional power of God, Puritans identified themselves with their Biblical equivalent, the Israelites and their covenant for the 'Promised Land.' Having ascertained their chosen position with reference to this initial evocation of the notion of 'Providence,' Winthrop renounces worldly princes and kings and highlights their inferiority to God's kingdom and his colonial 'Stewards,' thereby territorializing New England with this Biblical realm of Promised Land as 'the City upon a Hill:' ... we shall finde that the God of Israell is among us, when ten of us shall be able to resist a thousand of our enemies, when hee shall make us a prayse and glory, that men shall say of succeeding plantacions: the lord

12 “A Modell of Christian Charity” from Dreisbach \& Hall 2009, p. 123. 
Revisiting Americanus Novus:Anglicization Crisis and Salem Witch Trials in Seventeenth Century New England

make it like that of New England: for wee must Consider that wee shall be as a City upon a Hill, the eies of all people are upon us;... ${ }^{13}$

In addition to the notion of Providence, Winthrop introduces a peculiar sense of communal identity: For the persons, wee are a Company professing ourselves fellow members of Christ, in which respect onely though wee were absent from eache other many miles, and had our imployments as farre distant, yet we ought to account our selves knitt together by this bond of love, and live in the exercise of it, if wee would have comforte of our being in Christ, this was notorious in the practice of the Christians in former times,... ${ }^{14}$

Following this communal identity based on 'bond of love' and 'fellow members of Christ,' Winthrop announces his body politic:

...for the worke of wee have in hand, it is by mutuall consent through a special overruleing providence, and a more then an ordinary approbation of the Churches of Christ to seeke out a place of Cohabitation and Consorteshipp under a due forme of government both civill and ecclesiastiall. In such cases as this the care of the publique must oversway all private respects, by which not only conscience, but meare Civill policy doth binde us; for it is a true rule that particular estates cannot subsist in the ruine of the publique. ${ }^{15}$

In this respect, Winthrop's sermon departs from the Separatist Pilgrims' political and sectarian stances in The Mayflower Compact in the sense that he conforms to the English tradition of church-state government while at the same time bringing forth his Reformed ecclesiastical body politic. In addition to his Reformed ecclesiastical authority, Winthrop highlights a peculiar civic identity as an ideal party of a covenant with God:

Thus stands the cause between God and us, wee are entered into Covenant with him for his worke, wee have taken out a Commission, the Lord hath given us leave to drawe our owne Articles we have professed to enterprise these Actions upon these and these ends, wee have hereupon besought him of favour and blessing... ${ }^{16}$

Corresponding to this Providential perspective, Biblical typology of communal identity and remembrance as the main assets for resolving any transgressive acts against the authorities civil and divine, Winthrop's sermon "A Modell of Christian Charity" is a founding colonial text of a Reformed churchstate, independent of the Church of England, while still remaining its member with the Congregationalist identity. Thus, in search of an ideal / idyllic social

\footnotetext{
13 “A Modell of Christian Charity” from Dreisbach \& Hall 2009, p. 130-131.

14 “A Modell of Christian Charity” from Dreisbach \& Hall 2009, p. 129.

15“"A Modell of Christian Charity” from Dreisbach \& Hall 2009, p. 129.

16 “A Modell of Christian Charity” from Dreisbach \& Hall 2009, p. 130.
} 
justice in accord with their own moral perspective, the seventeenth century Puritan understanding of law and order in early colonial New England soon turned out to be a dystopia for the underrepresented colonial identities which were stratified in accordance with a highly oligarchic political and social order established on unequal formation of legal accesses determined by gender, race and class codes of the colony as it was seen in 1692-93 Salem witch trials. Nevertheless, Massachusetts Bay Colony achieved a quick success in comparison to other New England colonies, which became her satellites in her leading legal and political practices. Consequently, Plymouth Bay Colony was incorporated into Massachusetts Bay Colony in 1691. All in all, with regard to the initial colonial disintegration between the colony and metropole, and the colonial autonomy established by the magisterial authority, early New England period is believed to germinate the archetypal Anglo-American creole identity in Ralph Bauer's terms - up until the Second Charter of 1691, when the Massachusetts Bay Colony became a royal colony. Thenceforth came the Anglicization process and its offshoots in political, legal and religious grounds, which brought about a cultural crisis and hysteria as reflected in 1692-93 Salem witch trials. Thus, my focus will be on the rhetorical analysis of Cotton Mather's apology and theological justifications for Salem witch trials as a counter reaction to the Second Charter of 1691 and the consequent down fall of Calvinism with reference to his The Wonders of the Invisible World: Being An Account of the Tryals of Several Witches Lately Executed In New England (1692).

\section{Anglicization Crisis and Salem Witch Trials in Seventeenth Century New England}

As it was introduced in the previous section, the relevance of colonial perspective on the formation of American identity, through its inherent political and sectarian disintegration from the English background, can be surveyed in Cotton Mather's introduction to his Magnalia Christi Americana; or, Ecclesiastical History of New England (1702):

I WRITE the Wonders of the CHRISTIAN RELIGION, flying from the Depravations of Europe, to the American Strand. And, assisted by the Holy Author of that Religion, I do, with all Conscience of Truth, required therein by Him, who is the Truth itself, Report the Wonderful Displays of His Infinite Power, Wisdom, Goodness, Faithfulness, wherewith His Divine Providence hath Irradiated an Indian Wilderness. ${ }^{17}$

\footnotetext{
${ }^{17}$ Mather 1994, p. 259.
} 
Revisiting Americanus Novus:Anglicization Crisis and Salem Witch Trials in Seventeenth Century New England

Firstly, at the threshold of his text, Mather draws a distinction between New England's ecclesiastical formation and the Anglican Church of England as he denounces its authority and dogmatic hierarchies that were mostly inherited from its lineage with continental Catholicism. He depicts this phenomenon of colonial disintegration as an escape from the Old World bonds: "I WRITE the Wonders of the CHRISTIAN RELIGION, flying from the Depravations of Europe, to the American Strand." In this respect the sense of spatial disintegration is attached to a peculiar idea of a frontier between Europe and North America which is identified with the 'the American Strand' on the edge of transoceanic imperial powers namely that of Anglican and Catholic churchstates back in the Old World. However, in order to understand this colonial anxiety one should also take into account the whole colonial world of Americas initially established by the European Catholic empires. Secondly, as it is already paraphrased from John Winthrop's sermon "A Modell of Christian Charity" (1630), Mather endorses the early colonial sense of Providence: "wherewith His Divine Providence hath Irradiated an Indian Wilderness." Obviously, Mather aggrandizes the Puritan migration as a metaphoric Exodus, typifying the early settlers as the Biblical ancient Israelites and the Native American realm with that of the Philistines of Canaan, thereby giving a righteous cause to New England land encroachments. In his Hidden Genocide Hidden People (2014), Dennis Cerrotti names this colonial attitude as "the theology of encroachment" and evaluates its ideological influences on historical and contemporary conveyances of American identity:

The Puritans took their mission as one of exalted religious importance, believing that their success would inspire conversions to Christianity across the continent of America, often resorting to typological method to define themselves in relation to Native Americans. The Puritans were Jews, and the Native Americans the heathen - Philistines, Canaanites, Moabites and many other nations portrayed in biblical literature. Of course, this typology would prove deadly to Native Americans, even as it proved Puritan visionaries such as John Cotton, Increase Mather, Edward Johnson and many others also to make sense of their collective European plights in New England....Over and over again, we see this eschatological note in the thinking of Puritans, a note that is still strong in the undercurrents of contemporary American religious life. Thus, many Americans, as much as any other nation, persist in their belief in America as a Christian nation pre-ordained for greatness. Unfortunately, that same conviction has left behind a questionable legacy in colonial New England, one 
which is so painful to behold that it has been submerged beneath the great mythologies of this nation's founding. ${ }^{18}$

Hence, regarding these early founding narratives along with contemporary perspectives on colonial American identity, the scope of this study will present an overview on late seventeenth century colonial anxieties raised by the Second Charter and its Anglicization process which marked an ambivalent phase in colonial American experience. Thus, by examining the rhetorical representations of the Anglicization crisis with reference to theological and legal grounds for Salem witch trials in Cotton Mather's The Wonders of the Invisible World: Being An Account of the Tryals of Several Witches Lately Executed In New England (1692), this article aims to contribute to contemporary historicism on early colonial New England, whereby a nondiachronic formation of pre-Revolutionary American identity is widely presumed relying on the phenomena of initial colonial disintegration from metropole and autonomous American experience.

Nancy L. Rhoden defines the concept Anglicization as a "multifaceted process by which the mainland British colonies became more like England by the mid-eighteenth century," which "coincided with another process that we might label Anglicanization, the consolidation and expansion of the colonial Church of England." 19 Thus, along with its wider scope of eighteenth century, she also refers to North American Anglicization dispute raised in New England:

Anglicization can refer to the process of foreigners joining the English, as experienced by French Huguenots and some other non-English settlers, but it also might be useful to think of Anglicization as a process of reintroducing English culture, both traditional values and new strains of Englishness, to colonists of British background. In the case of Congregationalists in New England whose Puritan ancestors migrated largely in the early mid-seventeenth century, this makes considerable sense. Since each colony differed, its experience of Anglicization varied, and meanwhile England itself was evolving. Colonial contemporaries had to decide for themselves what constituted Englishness, among the divergent, changing threads. When English policies or values shifted, colonists had to decide which different strands they would imitate and which ones they would reject. Anglicization could include a reeducation about what British culture had become, but Anglican churchmen in Virginia did not necessarily want their colonial society remade in the post-1689 image of a more religiously tolerant England if that meant they would lose political and religious power to local dissenters. In a variety of ways,

\footnotetext{
${ }^{18}$ Cerrotti 2014, p. 35-36.

${ }^{19}$ Rhoden 2015, p. 125.
} 
Revisiting Americanus Novus:Anglicization Crisis and Salem Witch Trials in Seventeenth Century New England

Anglicization unleashed a contest over which English values were worthy of emulation. ${ }^{20}$

Rhoden's remarks on the devastating outcomes of political and sectarian centralization of Anglicization process in New England colonies are noteworthy for she emphasizes the historical discord between the late seventeenth century British culture and New England colony. Hence, as exemplified with the Anglican clergy of Virginia, "the post 1689 image of a more religiously tolerant England" did not count for New England's despotic regime over dissention. In this respect, Virginia example validates the idea that initial colonial disintegration and autonomy from the metropole London marked a uniquely American experience and identity regarding the fact that along with Calvinist Congregationalism of New England, colonial Anglicanism was also in great dissidence with the ideological undercurrents of late seventeenth century Anglicization. This sectarian divide between the Reformed colonial ecclesiastical experience and the metropole London's ecclesiastical norms of Anglicanism is depicted as a prominent anxiety behind the witchcraft hysteria in Cotton Mather's The Wonders of the Invisible World:

I hope in God's time it will be found, that among those that are thus cry'd out upon, there are persons yet Clear from the great Transgression; but indeed, all the Unreformed among us, may justly be cry'd out upon, as having too much of an hand in letting of the Devils into our Borders; 'tis our Worldliness, our Formality, our Sensuality, and our Iniquity that has help'd this letting of the Devils in. ${ }^{21}$

Among his alerting sentiments in evoking his criticism of the Anglicization process, Mather emphasizes the spread of sacramentalism of the Anglican Church of England in the colonies, which was one of the primary assets that the early Puritan settlers had strived to eliminate their Reformed churches from its influence. Thereby, he also draws a distinction between the "Reformed" and the "Unreformed" colonial settlers, transforming the physical sense of colonial border as an expression of an intra-imperial conflict between the colony and the metropole.

Given through the lens of this historical asymmetry between the colonial America and the metropole London, Cotton Mather's apology on Salem witch trials and executions, The Wonders of the Invisible World is a documentary work culminating the total sum of cultural anxieties and hysteria raised by the post-1691 Anglicization process. As a descendant of a distinguished family of Puritan divines, Richard Mather and Increase Mather, Cotton Mather was an

\footnotetext{
${ }^{20}$ Rhoden 2015, p. 127.

${ }^{21}$ Mather 2012, p. 95.
} 
established minister, scholar, and theologian when he was elected as the president of Harvard College in 1685. His book The Wonders of the Invisible World was published in 1692. He gave an account of the seven trials in Salem. Along with documentary testimonies and so-called eye-witness accounts, Mather compiled these witch trial accounts with his frame of Calvinist theology and the colonial cause of early Puritan body politic presenting a series of conception on the realm of Providence and its idea of covenant, representative of an ideal Christendom. Accordingly, out of his formulations, appeared a peculiar concept of a demon in relation with New England witchcraft.

Before examining Mather's grounds for framing the late seventh century New England witchcraft, a brief look at two early modern European accounts for witchcraft is required. One of these sources is Malleus Maleficarum (1486) written by Dominican friars and the other is Jean Bodin's On the Demon-Mania of Witches (1580). In his introduction to Malleus Maleficarum ("The Hammer of Witches"), Christopher S. Mackay states that "the work served to popularize the new conception of magic and witchcraft that is known in modern scholarship as satanism and diabolism, and it thereby played a major role in the savage efforts undertaken to stamp out witchcraft in Western Europe in the sixteenth and seventeenth centuries (a series of events sometimes known as witch craze)."22 Mackay also draws attention to the fact that this "witch craze" appeared in an age subsequent to the invention of the printing press in Germany by Johannes Gutenberg in 1450. Following these highlights Mackay's information about the authorial ethos of these two Dominican friars (Jacobus Sprenger and an unnamed collaborator) is essential for our evaluation of the phenomena with its ideological undercurrents:

As both men were Dominican friars, a few words about this institution may be helpful. The Order of Preachers (the official name of the order) was founded in the early thirteenth century to combat heresy. Though the Dominicans took the same sort of vows of poverty as monks, these friars did not withdraw from the secular world by joining monastery, but lived in society as part of their mission to root out heresy and enforce orthodoxy among the laity. Since the Order was intended to subvert heretical opposition in Church teachings, the Dominicans soon became involved in theological studies in order to sharpen their skills in spotting and rebutting heretical views.... These skills made it natural for the papacy to appoint Dominicans as inquisitors into heretical depravity. ${ }^{23}$

\footnotetext{
${ }^{22}$ Mackay 2006, p. 1.

${ }^{23}$ Mackay 2006, p. 2.
} 
Revisiting Americanus Novus:Anglicization Crisis and Salem Witch Trials in Seventeenth Century New England

Regarding the authorial intention of these Dominican writers in their urge for rooting out their contemporary phenomenon of heresy, which they identified with witchcraft; and the fact that Malleus Maleficarum was the most notorious body of work written on witchcraft from the early modern period, the prosecutions that were spread all over the following centuries in Europe and abroad can be seen as an outcome of the antecedent anxieties to be raised in the sixteenth century Reformation period. Consequently, along with sectarian schisms in Protestant Reformation, European civil wars, epidemics, and the political ambivalences observed in European kingdoms in the sixteenth century had reached their utmost degree of anxiety in transforming the Judeo-Christian Biblical literature of witchcraft from mere sorcery to demonology, through which the idea of demon was conveyed as a servant of God's wrath upon the Western Christian world, stressing the eschatological stretch of Christian notion of apocalypse. In this respect, Jean Bodin's On the Demon-Mania of Witches (1580) appeared as the second widely accepted handbook of early modern notion of witchcraft representing the culminating anxieties of the preceding century. In his introduction to Randy A. Scott's 2001 translation of On the Demon- Mania of Witches, Jonathan L. Pearl portrays the cultural and political environment of the sixteenth century Europe, particularly focusing on the rising tension created by Calvinism during the 1530s and the French religious wars between 1562 and 1595: "While the military phases of the civil war period were sporadic, religious propaganda and the political fighting went on ceaselessly. Each group accused its enemies of being in league with the Devil, and of committing the worst crimes imaginable against the state, God and the church." ${ }^{24}$ Thus, in a similar manner with the early modern European conveyance of Biblical demon image as a servant of the God's wrathful hand to the sectarian unrest raised by the Reformation, Cotton Mather's testimony of the seventeenth century Salem witch trials portrays a cultural hysteria against the decline of Puritan legacy and early communal projection of New England through the process of Anglicization : "It may cast some Light upon the Dark things now in America, if we just give a glance upon the like things lately happening in Europe. We may see the Witchcrafts here most exactly resemble the Witchcrafts there; and we may learn what sort of Devils do trouble the World." ${ }^{25}$ In addition to this analogy between the European witchcraft anxiety and Salem witchcraft trials, Mather justifies the severity of New England prosecutions comparing them to the severity of European prosecutions:

\footnotetext{
${ }^{24}$ Pearl 2001, p. 13.

${ }^{25}$ Mather 2012, p. 111.
} 
... such Spiritual Disorders as the whole World of abroad is overwhelmed with, to be as provoking in us, as the most flagitious Wickedness committed in other places; and the ministers of God are accordingly severe in their Testimonies: But in short, those Interests of the Gospel, which were the Errand of our Fathers into these Ends of the Earth, have been too much neglected and postponed and the Attainments of an handsome Education, have been too much undervalued, by Multitudes that have not fallen into Exorbitances of Wickedness; and some, especially of our young Ones, when they have got abroad from under the Restraints here laid upon them, have become extravagantly and abominably Vicious. ${ }^{26}$

Following this analogy between Europe and America, with his criticism on his contemporary religious education, by which he is obviously referring to post-1691 period of Anglicization in English colonies, Mather mourns that momentous "Exorbitances of Wickedness" going on in New England were an outcome of the fallen legacy of early founding Puritan fathers. Thirdly, Mather highlights a peculiar concept of Devil as analogous to early modern European demonology equivalent of heresy and witchcraft between 1450 and 1700 . In order to understand Mather's portrayal of demon as the servant of God's wrathful hand upon the world and his contemporary associations of witches as the servants of demon in his The Wonders of the Invisible World, two prominent motifs are noteworthy. One of these motifs is the palpability of demonic marks on the bodies of his followers and the idea of covenant between the demon and the witches. As it is understood from his title "The Wonders of the Invisible World," Mather tries to justify the realm of witchcraft as a reflection of an "invisible world." He calls this phenomenon as "wondrous" because he believes that witchcraft was the work of demon, through whom the wrathful hand of God was upon his contemporary Western Christian world. Paul Wise explains Mather's perspective of demon as a servant of God's wrathful hand in his doctoral dissertation, Cotton Mather's Wonders of the Invisible World: An Authoritative Edition:

Any study of The Wonders of the Invisible World must take into consideration the major event that occasioned Cotton Mather's book - the Salem witch trials. Providing a historical record of trials were the major pretext of Mather's book, but they almost always remain a subtext overshadowed by broad theological interpretations of witchcraft and events. Only by comparing what actually did happen with Mather's version of the events can we properly judge this apologia. What appealed to Cotton Mather was that the Salem witch frenzy brought many in New England at once into immanent contact with the

\footnotetext{
${ }^{26}$ Mather 2012, p. 12.
} 
Revisiting Americanus Novus:Anglicization Crisis and Salem Witch Trials in Seventeenth Century New England

invisible world. Proof of the Devil's wrath was proof of God. Mather took a great interest in investigating and documenting that world, for he had at times what he believed to be first-hand encounters with it himself. He thought himself fortunate to be able to witness and document events as they were occurring. He considered Salem a living laboratory for the recording of illustrious providences that would ultimately instill faith and set New England upon a more righteous path. Mather failed when he let his theology override reason because he considered the two to be identical. ${ }^{27}$

In the sense that Mather's text identifies witchcraft as a palpable wondrous reality and his theology overrides reason, in Paul Wise's terms, there is a stark resemblance with his The Wonders of the Invisible World (1692) and Jean Bodin's On the Demon- Mania of Witches (1580). Jean Bodin also states that "Whether then demons have fallen from the original grace in which they were created and they are immortal, as we maintain, ...and God made and formed Satan evil in order to destroy and ruin this elemental world, it must not, however, enter the minds of men that there is iniquity in God." ${ }^{28}$ A century earlier than New England witchcraft crisis, Bodin was also engaged in superstition despite his moderate Catholicism, his early modern political treatises and religious tolerance as he was essentially "influenced by Renaissance syncretism." 29 Thus, for a clear judgement on Mather's superstitions, a review on Renaissance and early modern science would be useful:

Learned occult conjuring and magical literature flourished in the early sixteenth century, along with such pseudo-sciences as alchemy and astrology. In their own way, the educated elites were as concerned with occult magic as were common people.... The best known author of magical works in Bodin's time was Heinrich Cornelius Agrippa of Nettesheim. Agrippa's most famous, or notorious, work was On the Occult Philosophy, published in 1531. While claiming to abhor witchcraft and heresy, Agrippa's work was a full account of many varieties of Renaissance magic, complete with "secrets" to help the reader to invoke the higher orders of the universe. ${ }^{30}$

In her Subject Matter: Technology, The Body, and Science on the AngloAmerican Frontier 1500-1676 (2003), Joyce E. Chaplin discusses the influence of this aspect of natural philosophy on English settlers' perspective of the natural world in America. In this respect, her remarks on the concurrence of

\footnotetext{
${ }^{27}$ Wise 2005, p. 2-3.

${ }^{28}$ Bodin 2001 p. $50-51$.

${ }^{29}$ Pearl 2001, p. 11.

${ }^{30}$ Pearl 2001, p. 16.
} 
theology and early modern science clarify Bodin's and Mather's amalgamation of theology with reason:

Natural philosophy was not a secular pursuit; all European views of nature were religiously informed. Indeed, theology was the paramount Scientia in the bundle of subjects that were collectively called sciences.

Natural philosophers combined rational deduction from occult phenomena with empirical examination of visible criteria. Nature was a concatenation of animating forces, a web of analogies, sympathies, and antipathies. A microcosm (such as the human body) reflected the structure and meaning of the macrocosm or cosmos. Humans could understand the cosmos through discovery of its invisible orders and visible workings. Copernicus, for instance, used empirically derived findings to support mystical conceptions of the creation. Some philosophers described how natural magic (contemplation and subtle manipulation of natural forces) elicited further wisdom and functioned as an efficacious way to control matter. This magic did not, like diabolic sorcery, force nature against itself; rather it utilized nature's own process to achieve its ends. Distinction between the empirical and mystical, or even between technology and magic, were not recognized. ${ }^{31}$

Furthermore, correlating the influence of natural philosophy to early English colonizers' hierarchy of learned sciences over Native Americans' sciences, Chaplin illustrates the perspective of English settlers on Native Americans' use of technologies through which they based their assumptions on the corporeal conditions of indigenous bodies. Her argument focuses on how English settlers' intellectual backdrop of natural sciences was influential on their observance and understanding of the New World. Moreover, she states that popularity of natural science due to the print culture of seventeenth century England was widely received because of its theological grounds and its foundations in classical learning. Besides underlining this binding ideological approach of early settlers to scientific thought, she focuses on the discursive correlation between the empire and science, which determined a particular colonial perspective and discourse within a nexus of political, economic, and cultural interactions between the settlers and Native Americans: "Popular conceptions of nature thus functioned as an educated but not learned set of assumptions about the natural world; these educated views, rather than learned discourse, were what informed writing on America." ${ }^{32}$ Thus, through the lens of this intellectual background, "Three sets of ideas were especially relevant for colonizers: hypotheses about the physical nature of new territories, information

\footnotetext{
${ }^{31}$ Chaplin 2003, p. 12-13.

${ }^{32}$ Chaplin 2003, p. 13-14.
} 
Revisiting Americanus Novus:Anglicization Crisis and Salem Witch Trials in Seventeenth Century New England

about technology appropriate to the resources of new places, and assessments of the human bodies suited to these places." ${ }^{33}$ Accordingly, she explores the ideological outcomes of settlers' observance on the susceptibility of indigenous bodies to European epidemics, which laid the foundations on the concept of race, use of technology and empiricism in early colonial rhetoric. In comparison to the strong immunity of the settlers to European diseases, the weakness of Native American bodies was a proof for their inefficiency both as a labor force and in terms of their use of technologies ranging from agricultural production to medical sciences. This colonial observance and its relevant discourse was convincing enough for the settlers' entitlement to Native American lands. As the science and technologies Native Americans were found ineffective and their bodies vulnerable to diseases, land encroachments of English colonizers were narrated as self-righteous and historically significant. Chaplin's focus on colonial perception of indigenous bodies is also crucial in the sense that this epistemic influence had brought about a politically transitional period from the early days of the settlements, which legitimized the colonial status of native people as "brethren," to the later stages of denial, assimilation and ethnic cleansing through a series of violent conflicts and wars between the colonizers and native tribes. Hence, as an exact example of the influence of the convergence between natural philosophy and Puritan theology on colonial identity formulations, Cotton Mather's demonization of Native Americans and their sciences as witchcraft represents his ideological ground for racial discrimination:

First, The Indian Powawes, used all their Sorceries to molest the first Planters here; but God said unto them, Touch them not! Then Seducing Spirits came to root in this Vineyard, but God so rated them off, that they have not prevail'd much farther than the Edges of our Land. After this, we have had a continual blast upon some of our ordinary Food. Herewithal, wasting Sickness, especially Burning and Mortal Agues, have Shot the Arrows of Death in our Windows. Next, we have had many Adversaries of our own Language, who have been perpetually assaying to deprive us of the English Liberties, in the encouragement whereof these Territories have been settled. As if this had not been enough; The Tawnies among whom we came, have watered our Soil with the Blood of many Hundreds of our Inhabitants. Desolating Fires also have many times laid the chief Treasure of the whole Providence in Ashes. As for Losses by Sea, they have been multiply'd upon us: and particularly in the present French War, the whole English Nation have observ'd that no part of the Nation has proportionably had so many Vessels taken, as our poor New-

${ }^{33}$ Chaplin 2003, p. 14. 
England. Besides all which, now at last the Devils are (if I may so speak) in Person come down upon us with such a Wrath, as is justly much, and will quickly be more, the Astonishment of the World. ${ }^{34}$

Within these lines, Mather gives an overall portrayal of his contemporary anxieties, devastating outcomes of the French War, natural disasters, and epidemics. And along with his conveyance of Native American sorcery on to witchcraft, he not only demonizes their indigenous sciences but also marginalizes them from his divine providence by evidencing their termination as God's wrath upon them. Moreover, he implies that as the English settlers' agricultural techniques were influenced by Native American sciences, their food was damaged and they suffered sicknesses. Having credited all the evils of his age onto Native American existence, be it literary or metaphorical, Mather's tension rises to the utmost level as he adds the Anglicization crisis to these prevalent anxieties:

But what will become of this poor New England after all? Shall we sink, expire, perish, before the short time of the Devil shall be finished? I must confess, That when I consider the lamentable Unfruitfulness of men, among us, under as powerful and perspicuous Dispensations of the Gospel, as are in the World; and when I consider the declining state of the Power of Godliness in our Churches, with the most horrible Indisposition that perhaps ever was, to recover out of this declension; I cannot but Fear lest it comes to this, and lest an Asiatic Removal of Candlesticks come upon us. ${ }^{35}$

Obviously, Mather's direct target is the Anglicization of New England, portraying the process as the work of Devil in bringing the colonies' total decline from the early founders' projections of 'A City upon a Hill': "Shall we sink, expire, perish, before the short time of Devil shall be finished?" He furthers his indications, underlining the Anglican influence of church relations and religious education system by saying, "when I consider the declining state of the Power of Godliness in our Churches..." Thus, through his depiction of Salem witchcraft delusion as a "wondrous" evidence of God's existence and wrath upon the perishing forces of evil identified via all aspects of colonial decline, he reflects his ideological discourse on colonial threats. Regarding this perspective, he fears that the remaining Native American existence in late seventeenth century still persists as cultural hybridity in English settlements, whereas the realm of witchcraft marks the decline of early ecclesiastical body politic under the influence of Anglicization process along with the ongoing

\footnotetext{
${ }^{34}$ Mather 2012, p. 74-75.

${ }^{35}$ Mather 2012, p. 75.
} 
Revisiting Americanus Novus:Anglicization Crisis and Salem Witch Trials in Seventeenth Century New England

political outcomes of this encounter. Despite his pessimism, though, he insists on seeing the process as a divine test upon the colony:

It's true, That thro' much Tribulation we must enter in the Kingdom of God; but a little before our Entrance thereinto, our Tribulation may have some sharper accents of Sorrow, then ever were yet upon it. And what is the cause of this? It is indeed the Faithfulness of our God unto us, that we should find the Earth more full of Thorns and Briars than ever, just before he fetches us from Earth to Heaven; and so we may go away the more willingly, the more easily, and with less Convulsion, at his calling for us. O there are ugly Ties, by which we are fastened unto this world; but God will by Thorns and Briars tear those Ties asunder. ${ }^{36}$

Thus, following his strong belief in the prevalence of early autonomous power of 'A City upon a Hill,' and seeing the contemporary decline of pious legacy as a divine test, his reference to Job empowers his eschatological sense of time, whence New England will at last gain its eternal salvation being an exemplary nation of posterity in glorifying God:

But, is not the hand of Job here? Sure, There is the wrath of the Devil also in it. A little before we step into Heaven, the Devil thinks with himself, My time to abuse that Saint is now but short; what Mischief I am to do that Saint, must be done quickly, if at all; he'l shortly be out of my Reach for ever. And for this cause he will now fly upon us with the Fiercest Efforts and Furies of his Wrath. It was allowed unto the Serpent, in Gen. 2.15. To Bruise the Heel. Why at the Heel, or at the Close, of our Lives, the Serpent will be nibbling, more than ever in our Lives before: and it is, Because now he has but short time. He knows, That we shall very shortly be, Where the wicked cease from Troubling, and where the Weary are at Rest; wherefore that Wicked one will now Trouble us, more than ever he did, and we shall have so much Disrest, as will make us more weary than ever before, of things here below. ${ }^{37}$

Next to Job, Mather refers to Genesis, whereby the tempter serpent is punished: "I will put enmity between you and the woman, and between your offspring and hers; he will strike your head, and you will strike his heel"38 According to the New Testament prophesy, these lines refer to the coming of Jesus Christ as the fallen "offspring of Eve" will strike the head of the serpent under the feet of Virgin Mary. In terms of Mather's emphasis on all the wicked forces troubling his pious nation, the Biblical serpents' perpetual strike at the heel of the "fallen offspring" of Adam is underlined: "He knows, That we shall

\footnotetext{
36 Mather 2012, p. 64.

${ }^{37}$ Mather 2012, p. 64-65.

${ }^{38}$ Genesis 3:15
} 
very shortly be, Where the wicked cease from Troubling, and where the Weary are at Rest; wherefore that Wicked one will now Trouble us, more than ever he did...” Thus, along with all the undercurrent outcomes of the Anglicization in his era, be it the witchcraft or the Native American or extra-imperial unrest through the wars, Mather strives to provide a rising tension to his contemporary colonial readers as well as future Americans with the idea that New England will be a nation of future in glorifying God both on earth and Heavenward. He stresses his belief that as a chosen nation among others in his contemporary Christendom, New England became an open target for the Devil's pervasive ends:

Accordingly, why may not some Devils be more accomplished for what is to be done in such and such places, when others must be detach'd for other Territories? Each Devil, as he sees his advantage, cries out, Let me be in this Countrey, rather than another.... Hence'tis, that he cannot bear the Name of God should be acknowledged in the World: Every acknowledgement paid unto God, is a fresh drop of the burning Brimstone Calling upon the Devil; he does make his Insolent, tho' Impotent Batteries, even upon the Throne of God himself: and foolishly affects to have himself exalted unto that Glorious High Throne, by all people, as he sometimes is, by Execrable Witches. ${ }^{39}$

Drawing the colonial image of his contemporary New England coming under the domain of Devil's wrath both because of being a pious land and also as a fallen land under Anglicization, his "Execrable Witches" appear as the representation of all the evil forces among other wicked occurrences surrounding the place:

Plagues are some of those woes with which the Devil troubles us... Pestilential and Contagious Diseases, 'tis the Devil who does oftentimes invade us with them.... Again, Wars are also of those Woes with which the Devil causes our Trouble.... We read concerning Damoniacks, or People in whom the Devil was, that they would cut and wound themselves; and so, when the Devil is in Men, he puts 'em upon dealing in that barbarous fashion with one another.... Once more, why may not Storms be reckoned among those Woes, with which the Devil does disturb us? It is not improbable that Natural Storms on the World are often on the Devil's rising.... Whence perhaps it is that Thunders are observed oftener to break upon Churches than upon any other Buildings; and besides many a Man, yea many a Ship, yea, many a Town has miscarried, when the Devil has been permitted from above to make an horrible Tempest. ${ }^{40}$

\footnotetext{
${ }^{39}$ Mather 2012, p. 46-47.

${ }^{40}$ Mather 2012, p. 52- 53-54.
} 
Revisiting Americanus Novus:Anglicization Crisis and Salem Witch Trials in Seventeenth Century New England

One Woe that may be look'd for is, A frequent Repetition of Earthquakes, and this perhaps by the energy of the Devil in the Earth. The Devil will be clap't up, as a Prisoner in or near the Bowels of the earth, when once that Conflagration shall be dispatched, which will make, the New Earth wherein shall dwell Righteousness; and that Conflagration will doubtless be much promoted, by the Subterraneous Fires, which are a cause of the Earthquakes in our Dayes. ${ }^{41}$

And behold, This very Morning, when I was intending to utter among you such Things as these, we are cast into and Heartquake by Tidings of an Earthquake that has lately happened at Jamaica: an horrible Earthquake, whereby the Tyrus of the English America, was at once pull'd into the Jaws of the Gaping and Groaning Earth, and many Hundreds of the Inhabitants buried alive. The Lord sanctifie so dismal a Dispensation of his Providence, unto all American Plantations! But be assured, my Neighbours, the Earthquakes are not over yet! We have not seen the last. And then, Another Wo that may be Look'd for is, the Devil's being now let Loose in preternatural Operations more than formerly; and perhaps in Possessions and Obsessions that shall be very marvelous.... That there will again be an unusual Range of the Devil among us, a little before the Second Coming of our Lord, which will be, to give the last stroke, in Destroying the works of Devil. ${ }^{42}$

Last but not least, Mather's depiction of the epidemics, wars and natural disasters of his era as "preternatural Operations" confirms his portrayal of Salem witchcraft as one of the multiple forces dismantling his New England, the divine providence once assigned to the founding forefathers of the colony. As he underlines this undercurrent, he does not hesitate to target the churches of his era by conveying the realm of storm as a natural disaster onto the contemporary re-ordering of New England ecclesiastical authority under the domain of the Church of England with the Second Charter: "However that the Devil has raised many Metaphorical Storms upon the Church, is a thing, that which there is nothing more notorious." 43 His statement, "that Thunders are observed often to break upon Churches than upon any other Buildings" becomes more open when he restates this implication as: "an unusual Range of the Devil among us.” Thus, his judgement on the Anglicization process of New England is most explicit within these sentences:

I say, Thirdly, That as it fares with Old England, so it will be most likely to fare with New-England. For which cause, by the way, there may be more of

\footnotetext{
${ }^{41}$ Mather 2012, p. 60.

${ }^{42}$ Mather 2012, p. 61.

${ }^{43}$ Mather 2012, p. 54.
} 
the Divine Favour in the present Circumstances of our dependence on England, than we are all well aware of. This is very sure, if matters go ill with our Mother, her poor American Daughter here, must feel it; nor could our former Happy Settlement have hindered our sympathy in that Unhappiness. But if matters go Well in the Three Kingdoms; as long as God shall bless the English nation, with Rulers that shall encourage Piety, Honesty, Industry, in their Subjects, and that shall cast a Benign Aspect upon the Interests of our Glorious Gospel, Abroad as well as at Home; so long, New-England will at least keep its head above water: and so much the more, for our comfortable Settlement in such a Form as we are now cast into. Unless there should be any singular, destroying, Topical Plagues, whereby an offended God should at last make us Rise; But, Alas, O Lord, what other Hive hast thou provided for us! $!^{44}$

From this point on, his distress about New England coming under the domain of "Old England" with the Second Charter in 1691, gains a political stance which strikingly sounds as a germinating root of pre-Revolutionary colonial identity. He reflects his utter resentment on the Anglicization of New England, having lost its initial disintegrated autonomous colonial cause, which was encouraged by the first royal charter of 1629 . Now, under the domain of a centralized authority of the metropole London and the Church of England, Mather mourns for the fact that the current situation of his commonwealth is pushed towards an ambivalent period, whence the political, economic and cultural ties to "Old England" or namely the "Mother" of his "poor American daughter" will bring about the fall of New England. Nevertheless, he insists that New England will prevail in the future of America by saying "New England will at least keep its head above water." Then, his belief in the prospect of New England seems to resonate in the future pre-Revolutionary cause:

I say, First, That surely, America's Fate, must at the long run include New-Englands in it. What was the design of our God, in bringing over so many Europceans hither of later years? Of what use or state will America be, when the Kingdom of God shall come? If it must all be the Devil's propriety, while the saved Nations of the other Harmisphere shall be Walking in the Light of the New Jerusalem, Our New England has then, 'tis likely, done all that it was erected for. But if God have a purpose to make here a seat for any of those glorious things which are spoken of thee, $O$ thou City of God; then even thou, $\boldsymbol{O}$ New England, art within a very little while of a better days than ever yet have dawn'd upon thee. ${ }^{45}$

\footnotetext{
${ }^{44}$ Mather 2012, p. 77.

${ }^{45}$ Mather 2012, p. 76.
} 
Revisiting Americanus Novus:Anglicization Crisis and Salem Witch Trials in Seventeenth Century New England

\section{Conclusion}

Whatever future aspirations were inherent in Cotton Mather's projection of New England, he was astute in most of his remarks. Today's northeastern states of the United States still prevail as emblematic of the centralized power of politics, finance, and culture. Furthermore, regarding their political and cultural influence in pre-and post-Revolutionary processes including the Antebellum and the post-Civil War periods, northeastern strand of the U.S. became a center, whereby the rest of the nation came under its domain as the satellite regions all throughout these historical phases. Relying on this cultural stance, early colonial New England experience has been portrayed with a peculiar American identity marking a break with earlier "Englishness" as it is examined through the founding texts in the first section. In the early seventeenth century, this rhetorical seclusion from the metropole found its correspondence in the Biblical image of American wilderness, whereby the pioneers took their task of building their 'City upon a Hill' just like Moses had his errand in the wilderness leading his Israelites. Nonetheless, through its magisterial regime of body politic in oppressing dissention and any form of transgression from the communal norms, be it the witchcraft, Quakerism, Baptism or Native Americans, early New England historicism put forward a homogenizing communal colonial outlook. Accordingly, piety came to represent this overemphasized aspect of New England as the initiation myth of Anglo-American identity. However, recent studies on colonial America also question this totalizing non-diachronic evolution of pre-Revolutionary identity derived initially from its break with "Englishness" (by founding the colony) towards an American identity (by the pre-and post-Revolutionary phases) as well as questioning the diachronic approach to the process of becoming American from "Englishness." In their introduction to Anglicizing America (2015), Ignacio Gallup-Diaz, Andrew Shankman, and David J. Silverman state that:

Regardless of where one stands in the debate, any scholar interested in the early modern empire and the American Revolution must contend with the concept of Anglicization.

The early twenty-first century is an opportune time to revisit the idea of Anglicization. For the past thirty years, early American historians have been drifting away from the traditional centerpiece of the field - the thirteen mainland British colonies and their advance to revolution and nationhood toward topics that their predecessors usually treated only tangentially. These themes include the British Caribbean, Native Americans, slavery, transatlantic migrations and other European colonies. Recent scholarship sees colonial America not as the prologue to the United States but instead as convergence 
and clash of many peoples and imperial powers across the hemisphere over the course of three centuries. ${ }^{46}$

Regarding these recent debates, then, as a challenge to the mainstream historicism on mainland North American English colonies as homogenously populated societies, which overlooked the reality of diversity in colonial population, contemporary studies like Margaret Ellen Newell's Brethren by Nature (2015) and Wendy Warren's New England Bound (2016) illuminate a clearer depiction of early colonial New England. In contrast to earlier mainstream representations of the era, Newell and Warren highlight the hidden and underrepresented culture of servitude and slavery and they deconstruct the biased representations of race and class relations with reference to colonial politics and legal practices on Native American enslavement and African slavery. What really mattered was to what extent these colonial subjects could be treated in legal terms. Moreover, such new perspectives in the field also reverse the mainstream popular image of early colonial forefathers, depicting their moral double standards in resolving the intra-and extra-imperial matters both with other Europeans and Native Americans as it was evident in the Pequot War (1636-1638). Dennis Cerrotti’s Hidden Genocide Hidden People (2014) gives us another alternative portrayal of the theological history of early New England with reference to the relations between English settlers and Native Americans. His definition of the "theology of encroachment" underlines the moral decline of the 'City upon a Hill.' Instead of a self-righteous historical significance attached to colonial forefathers and magistrates like William Bradford and John Winthrop, Cerrotti's questionings on the discursive practices on Native American land politics and conflicts lead us to re-question how representation mattered in such colonial societies of highly diverse populations. As a ground for these recent historicisms on colonial perception of difference, Karen Ordahl Kupperman's Providence Island: The Other Puritan Colony (1993) brings forth an elaborative perspective on the transoceanic connections of early New Englanders. According to Kupperman, in their attempts to establish a colony at the heart of Catholic New Spain and Caribbean, New England Puritans were not spared from the ideological dilemmas and consequences of this transatlantic trade:

Working on the history of Providence Island made me see that we have artificially cut up the early English colonial effort into hermetically sealed units, New England (usually only Massachusetts Bay) and the Chesapeake and have ignored massive evidence of an integrated colonial vision that was widely

${ }^{46}$ Gallup-Diaz, Shankman, \& Silverman 2015, p. 1-2. 
Revisiting Americanus Novus:Anglicization Crisis and Salem Witch Trials in Seventeenth Century New England

shared on both sides of the Atlantic. The backers of Virginia, Bermuda, Massachusetts, Connecticut and Maine settlements, and they advised on others. ${ }^{47}$ Kupperman furthers her argument by underlining the significance of this colonial economic base. Thus, land ownership granted by colonial charters was one of the main aspects of colonial system that gave a stimulus for administrative and theological ascendance to the Puritan settlers: "For leading Puritans, religious commitment meant empowerment. Charles Cohen argues that puritans were obsessed with the limits of human ability. But regeneration, a sense of personal election, conferred power through focusing on one's energies and attention combined with a conviction of correctness of one's goals." ${ }^{48}$ In general, as an outcome this colonial economic base, the conditions of Native Americans and African slaves, any colonial subjects, who were not free males and without the right of property and protection by the laws, were exposed to severe political and punitive codes for the uneven disputes with the authorities. This type of legal inferiority was also prevalent in dealing with free colonial subjects who were Antinomians or disobedient to the magisterial enactments of the colonial jurisdictions as examined in Cotton Mather's Salem witch trials account, The Wonders of the Invisible World: Being An Account of the Tryals of Several Witches Lately Executed In New England. The price for any kind of deviancy from the colonial rules meant fines, corporal punishments, expulsion from the colony or dying on gallows as a last resort.

Thus, in this study, the Puritan colonial conveyance of criminality as a sign of God's wrath upon the once exemplary community's decline under the domain of Anglicization period in post-1691 New England is exemplified with Cotton Mather's account of Salem witch trials. In this respect, The Wonders of the Invisible World: Being An Account of the Tryals of Several Witches Lately Executed In New England was identical with the precedent examples of witchcraft testimonies in early modern Europe with reference to Malleus Maleficarum and Jean Bodin's On the Demon-Mania of Witches. Affirming to the rhetorical aspects of these earlier texts on the superstitious sense of demonology exposed as the wrathful hand of God in answering their contemporary crisis and hysteria, Mather's book brought about a peculiar definition of demonology as a portrayal of Anglicization process dethroning the early colonial autonomy of Puritan legacy in late seventeenth century. Lastly, rather than questioning the legal grounds for the Salem witch trials and scientific validity of witchcraft as an already worn out conception of sorcery or demonology, Mather's points are representative of a cultural regression of his

\footnotetext{
${ }^{47}$ Kupperman 1993, p. ix

${ }^{48}$ Kupperman 1993, p. 4.
} 
age as well as representing the earlier historical asymmetry between the metropole "Old England" and colonial New England.

All in all, as allegorized by American playwright Arthur Miller's 1953 play The Crucible, the delusion of witchcraft in Salem witch trials, which took place in Massachusetts Bay Colony in 1692-93, is conveyed through the Cold War cultural hysteria of McCarthyism's "witch hunt," pursued on the threat of communism in the U.S. Moreover, having witnessed the last thirty years of demonizing political discourses in and abroad the U.S., this twentieth century allegorical representation of Salem witch trials by Arthur Miller persists in its perspective of American history and culture. Hence, a revisit to early Americanus Novus would help us understand today's dilemmas as observed through social, political and legal inequities in and abroad the U.S., despite a legal culture which is inherently pre-and post-Revolutionary and all-American. 
Revisiting Americanus Novus:Anglicization Crisis and Salem Witch Trials in Seventeenth Century New England

\section{BIBLIOGRAPHY}

Bauer 2009

Bhabha 1993

Bodin 2001

Cerrotti 2014

Chaplin 2001

Donegan 2002

Dreisbach 2009

Gallup-Diaz 2015

Genesis 2010

Kupperman 1993

Mather 2012

Mather 1994

Mackay 2006
Ralph Bauer \& Jose Antonio Mazzotti, Creole Subjects in the Colonial Americas: Empires, Texts, Identities, The University of North Carolina Press.

Homi K. Bhabha. Nation and Narration, Routledge.

Jean Bodin, On the Demon-Mania of Witches. Randy A. Scott (trans.), Center for Reformation and Renaissance Studies.

Dennis Cerrotti, Hidden Genocide Hidden People. Sea Venture Press.

Joyce E. Chaplin, Subject Matter: Technology, the body and science on the Anglo-American Frontier, 1500-1676, Harvard University Press.

Kathleen Donegan, “'As Dying, Yet Behold We Live' Catastrophe and Interiority in Bradford's Of Plymouth Plantation," Early American Literature, vol. 37, no. 1, 2002, pp. 9-37. The University of North Carolina Press.

Project Muse. https://muse.jhu.edu/article/9722

(Accessed on 20 Dec 2017)

Daniel L. Dreisbach \& Mark David Hall (eds.), The Sacred Rights of Conscience. Selected Readings On Religious Liberty And Church-State Relations In The American Founding, Liberty Fund.

Ignacio Gallup-Diaz, Andrew Shankman, \& David J. Silverman (eds.), Anglicizing America. Empire, Revolution, Republic, University of Pennsylvania Press.

Genesis, The New Oxford Annotated Bible. New Revised Standard Version With The Apocrypha. Oxford University Press.

Karen Kupperman Ordahl, Providence Island, 1630-1641: the Other Puritan Colony, Cambridge University Press.

Cotton Mather, The Wonders of the Invisible World: Being An Account of the Tryals of Several Witches Lately Executed In New England, Forgotten Books.

Cotton Mather, "Introduction" from Magnalia Christi Americana; or, The Ecclesiastical History of New-England," Early American Writing. Giles Gunn (ed.), Penguin Books.

Christopher S. Mackay (trans.), "Introduction." The Hammer Of Witches ("Malleus Maleficarum"), Cambridge University Press. 
McManus 1993

Newell 2015

Nelson 2008

Pearl 2001

Rhoden 2015

Warren 2016

Weber 2001

Wise 2005
Edgar J. McManus, Law and Liberty in Early New England. Criminal Justice and Due Process, 1620-1692, The University of Massachusetts Press.

Margaret Ellen Newell, Brethren by Nature: New England Indians, Colonists, and the Origins of American Slavery, Cornell University Press.

William E. Nelson, The Common Law in Colonial America: Chesapeake and New England, 1607-1660, (Volume 1), Oxford University Press.

Jonathan L. Pearl, "Introduction," On the Demon-Mania of Witches, Jean Bodin. Randy A. Scott (trans.), Center for Reformation and Renaissance Studies.

Nancy L. Rhoden, "Anglicanism, Dissent, and Toleration in Eighteenth-Century British Colonies," Anglicizing America. Empire, Revolution, Republic, Ignacio Gallup-Diaz, Andrew Shankman, \& David J. Silverman (eds.), University of Pennsylvania Press.

The Charter of Massachusetts Bay

Retrieved from The Avalon Project.

The Documents in Law, History and Diplomacy. Yale Law School. Lillian Goldman Law Library. https://avalon.law.yale.edu/17th_century/mass03.asp

(Accessed on 7 November 2019)

Wendy Warren, New England Bound: Slavery and Colonization in Early America. First ed., Liveright Publishing Corporation.

Max Weber, The Protestant Ethic and the Spirit of Capitalism, Routledge.

Paul Melvin Wise, "Cotton Mather's Wonders of the Invisible World: An Authoritative Edition,” Dissertation, Georgia State University. http://scholarworks.gsu.edu/english_diss/5

(Accessed on 20 October 2017) 